\title{
Litter Parameters and Spontaneous Abnormalities in Himalayan Rabbits
}

\author{
Horst LEHMANN, Asaki MATSUO*, Adolf NIGGESCHULZE** \\ and Alexander KAST* \\ Dr. Karl Thomae GmbH, 7950 Biberach an der Riss FR Germany, *Nippon \\ Boehringer Ingelheim Co., Ltd., 103 Takada, Yato, Kawanishi \\ Hyogo (666-01) Japan, and **Boehringer Ingelheim LKG, \\ 6507 Ingelheim am Rhein FR Germany.
}

(Received 10 December 1985/Accepted 14 March 1986)

\begin{abstract}
A joint study was undertaken in three testing facilities to evaluate cumulative background data of Himalayan rabbits. All litters were derived from control does. The conception rate was high (84.0-95.1\%) but the average numbers of corpora lutea (7.9-8.7), implantation sites (6.5-7.5) and viable fetuses (5.8-6.9) were somewhat lower than that of most other strains of rabbit. Altogether 90 malfomed fetuses (1.12 $\%$ ) and 425 fetuses with variations (5.27\%) occurred among 8,060 virable fetuses.
\end{abstract}

The Himalayan rabbit has been bred by us in closed colonies since 1966. In two previous papers $[7,10]$ the advantages of Himalayan rabbits, the general features of their fertility, reproduction and growth have been reported, and their practical suitability in reproduction toxicology testing, such as higher conception and weaning rate, and lower body weight have been discussed. In their compilation, Kameyama et al. [4] have published the teratologic background data of rabbits from various sources in Japan already including some data on $\mathrm{Hi}$ malayan rabbits. The litter parameters and spontaneous abnormalities of Himalayan rabbits obtained from control does from teratologic studies are presented in this paper. The joint study combines data from 3 testing facilities of the Boehringer Ingelheim group, Labs 1-3.

\section{Material and Methods}

Rabbits of Labs 1 and 3 were purchased continuously for each study from the experimental animal breeding center of Dr. Karl Thomae $\mathrm{GmbH}$, as was the first breeding group of Lab 2 in 1971 . Since then, the Himalayans were random-bred at Lab 2 in a closed colony, while at Dr. Karl Thomae GmbH, supplier for Labs 1 and 3, animals were not rigorously bred at random, but selected according to their litter size $[7,10]$.

Does were at least 16 -weeks old, weighing $2328 \pm 83 \mathrm{~g}$ (Lab 1), $2207 \pm 263 \mathrm{~g}$ (Lab 2) and $2350 \pm 97 \mathrm{~g}$ (Lab 3) at the beginning of trial. All does were inseminated twice in the morning and were considered fertilized when the buck both times wearily collapsed. A male usually succeeded in inseminating two females within $30 \mathrm{~min}$. This day was counted as day 0 of pregnancy. Standardized pelleted dry food (fortified $9970 \mathrm{~S}$, Altromin $\mathrm{GmbH}$, Lage (Labs 1 and 3)), CR-1 (Clea Japan Co. Ltd., Osaka (Lab 2)), and tap-water from drinking bottles were available ad libitum.

All does were controls vehicle-treated during organogenesis and were killed on day 29 of gestation. Immediately after uterine incision, the number of fetuses, their placement in the uterine horns, correlation with the number of corpora lutea, the number of viable 
and dead fetuses, and the number of early and late resorptions were determined per doe. Viable fetuses were weighed, given an identity number and examined for external abnormalities, sexed and examined for skeletal abnormalities using radiography. Thereafter, the fetuses were subjected to autopsy and examined for cephalic abnormalities by razor blade sections. Abnormalities were classified following Palmer $[11,12]$ modified according to nowadays standards.

\section{Results}

Deaths among pregnant does were rare: six at Lab 1, from unknown reasons, two at Lab 2 , namely one from an accident and the other from catarrhal enteritis; 11 at Lab 3, namely four from misapplication, one from gastroenteritis and six from trauma. The litter parameters of Himalayan rabbits are shown in Table 1, the findings in fetuses listed in Tables 2 and 3.

\section{Discussion}

Between the three Labs compared, the conception rate of our Himalayan rabbits was between $84.0 \%$ and $95.1 \%$. If compared with data published for other strains of rabbit (Table 4), this is distinctly higher than that of Japanese White (JW) and most other strains. Abortions (0.4-3.1\%) compared well with most other colonies. The incidence of does with total resorption $(0.4-1.7 \%)$ was either very low or lay between that of New Zealand White rabbits (NZW), which also had low values, and that of the other strains showing a higher percentage of fetal loss.

The average numbers of corpora lutea (7. 9-8.7) and implantation sites (6. 5-7.5) per litter were lower than for NZW, most JW and "hare-rabbits" but higher than for Silver Fawns. The percentage of dead implants to implantation sites was about 7. 8-12.1\%, This was rather high compared to the Silver Fawn rabbit, but compared well with NZW. The percentage lay within the wide range of $\mathrm{JW}$ rabbit data, and was markedly lower than that of the "hare-rabbits." However, the average small litter size of Himalayans (5.8-6.9) was rather small compared with all other strains except Silver Fawns (Table 4).

There were also marked differences between the 3 Labs keeping the Himalayan rabbits, although the animals originate from the same source [10]. Conception rates and litter parameters in particular, differed greatly. The different breeding strategy may account for differences in conception rate between Labs 1 and 3 versus Lab 2 . The conception rate is remarkably higher in the latter compar ed with Labs 1 and 3 where the insemination became difficult-a problem unknown in Lab 2 . Also, the slightly lower average body weight at Lab 2 may indicate that the does were younger and, therefore, their conception rate higher. Other interlaboratory differences like litter size cannot be attributed to the breeding procedures nor to feed ingredients. These factors are identical in Labs 1 and 3 where differences are more pronounced than between Labs 2 and 3. Whether geographic or minor housing differences may influence such parameters remains to be understood.

In rabbits the rate of abnormalities is relatively high, namely near or above $1 \%$ of viable fetuses $[1,11]$. By external examination, 30 of our fetuses (Table 2) showed malformations (0.37\%) and among them omphalocele was most common $(4 / 8060=0.05 \%)$.

This is somewhat lower than the incidence of $0.08 \%$ omphalocele reported in NZW fetuses [12], and $0.11-0.25 \%$ in JW rabbits [4].

A total of 37 Himalayan fetuses showed skeletal abnormalities (0.46\%). Among them, deformities of vertebral bodies or arches and ribs $(0.16, \%)$ are rather common in rabbits, namely $0.12 \%$ in NZW [12] and $0.58 \%$ in JW [9]. Fused sternebrae (0.29\%) were also reported by Palmer in much higher frequency in NZW (1.26\%).

Among the 33 visceral abnormalities (0.41 ó), renal defects were relatively common in Himalayan rabbits in Lab 2, namely altogether $5 / 2247(0.22 \%)$, but did not occur in either of the other colonies and were rare in JW, "harerabbits" and Silver Fawns $[2,4,9,15]$. They were observed, however, in fetuses of NZW $(0.11 \%)$ [12]. Cardiovascular malformations 


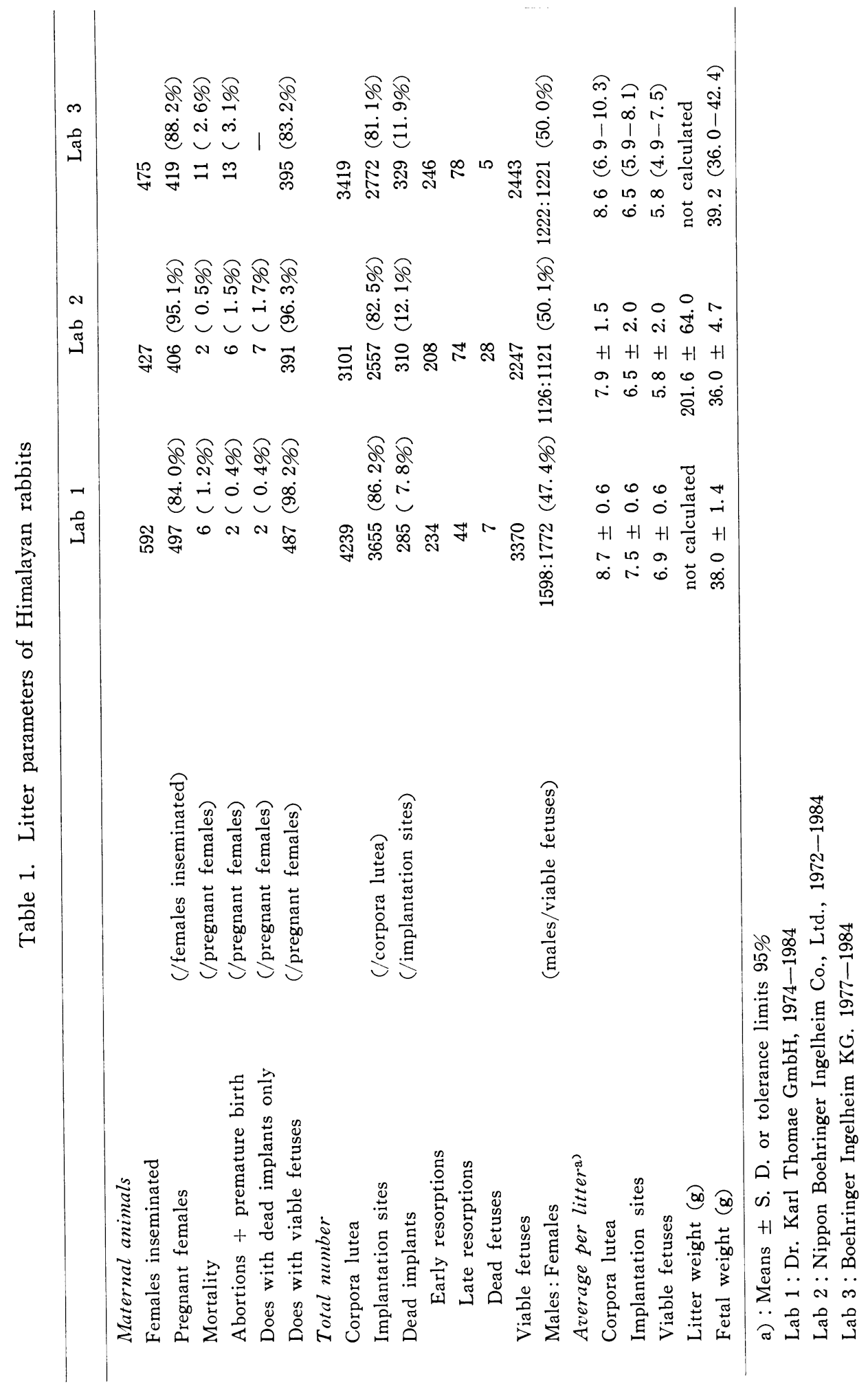


Table 2. Malformations found in fetuses of Himalayan rabbits

Number of litters examined
Number of fetuses examined
Number of litters with malformed fetus
Number of fetuses with malformation
(External examination)

Anasarka

Schistosoma reflexum + amelia \& cleft palate

Multiple arthrogryposis

Cranioschisis

Acephaly

Acrania (Monster)

Acrania with gastroschisis and absence of gallbladder

Acrania and omphalocele

Exencephaly + open eye \& cleft plate

Encephalocele

Meningocele

Anophthalmia + cleft lip \& cleft palate \& absent upper incisivi \& hydrocephaly

Brachygnathia

Gnathopalatoschisis

Cleft palate

Scoliosis

Scoliosis + cleft palate

Ectopia cordis

Gastroschisis

Omphalocele

Omphalocele and renal agenesia

Omphalocele, fused sternebrae and renal caudaposition

Absense of thumb (Oligodactyly)

Micromelia

Kinked tail

(Skeletal examination)

Composed anomaly of thoracic spine

Cleft and blocked vertebrae

Reduced number of vertebrae

Hemivertebra

Fused ribs

Branched ribs

Fused sternebrae

(Visceral and cephalic examination)

Hydrocephaly

Hydrocephaly + cleft palate

Dextroposition of Aorta

Truncus arteriosus persistent with septal defect of the heart
Lab 2

Lab 3

\section{Lab 1}

487

3370

391

2247

395

33 (6. $78 \%)$

21

21 (5.37\%)

2443

36 (1.07\%)

24 (1.07\%)

27 (6. 84\%)

30 (1.23\%)

$2(0.06 \%)$
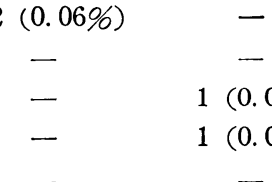

1 (0.04\%)

$1(0.04 \%)$

$2(0.06 \%)$

$1(0.03 \%)$

$1(0.04 \%)$

-

$1(0.04 \%)$

-

-

1 (0.03\%)

$1(0.03 \%)$

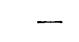

-
$2(0.06 \%)$
$1(0.03 \%)$
$1(0.03 \%)$
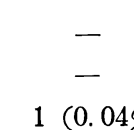

$1(0.04 \%)$

$1(0.04 \%)$

$\begin{array}{ccc}1(0.03 \%) & - & - \\ - & 1(0.04 \%) & 1(0.04 \%) \\ - & - & 1(0.04 \%) \\ 1(0.03 \%) & 1(0.04 \%) & - \\ 1(0.03 \%) & - & - \\ 1(0.03 \%) & - & - \\ - & 1(0.04 \%) & - \\ - & 1(0.04 \%) & - \\ 1(0.03 \%) & - & - \\ - & 1(0.04 \%) & - \\ - & - & 1(0.04 \%)\end{array}$

$-$

$3(0.13 \%)$

$1(0.04 \%)$

$1(0.03 \%)$

$1(0.04 \%)$

3 (0.12\%)

$1(0.03 \%)$

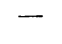

$1(0.03 \%)$

$1(0.04 \%)$

-

$1(0.04 \%)$

$9(0.27 \%)$

5 (0.22\%)

$9(0.37 \%)$

$1(0.03 \%)$

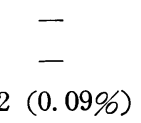

$2(0.08 \%)$
$2(0.09 \%)$

$2(0.06 \%)$ 
Truncus arteriosus persistent with cor triloculare univentriculi

Absence of gallbladder

$2(0.06 \%)$

$10(0.30 \%)$

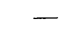

$-$

$7(0.29 \%)$

Double gallbladder

Renal agenesia

-

$1(0.04 \%)$

Renal caudaposition

$2(0.09 \%)$

$1(0.04 \%)$

Table 3. Variations found in fetuses of Himalayan rabbits

\begin{tabular}{lccc}
\hline & Lab 1 & Lab 2 & Lab 3 \\
\hline Number of litters examined & 487 & 391 & 395 \\
Number of fetuses examined & 3370 & 2247 & 2443 \\
Number of litters with variated fetus & $128(26.28 \%)$ & $75(19.18 \%)$ & $82(20.76 \%)$ \\
Number of fetuses with variation & $234(6.94 \%)$ & $96(4.27 \%)$ & $95(3.89 \%)$ \\
$\quad$ Generally delayed ossification & $2(0.06 \%)$ & - & - \\
$\quad$ Enlarged fontanelle posterior & - & - & $1(0.04 \%)$ \\
Delayed ossification of the skull & $1(0.03 \%)$ & - & - \\
Slightly dilated cerebral ventricles & $4(0.12 \%)$ & - & - \\
Retina folds & $154(4.57 \%)$ & - & - \\
Dilated cardiac ventricles & $13(0.39 \%)$ & - & - \\
Abnormal lobulation of lungs & $13(0.39 \%)$ & $2(0.09 \%)$ & - \\
Agenesia of accessory lobe of lung & - & - & $49(2.01 \%)$ \\
Split of sternebrae & - & $3(0.13 \%)$ & $1(0.04 \%)$ \\
Asymmetry of sternebrae & - & $3(0.13 \%)$ & $4(0.16 \%)$ \\
13 th ribs & $3(0.09 \%)$ & $65(2.89 \%)$ & $11(0.45 \%)$ \\
Short 12 th ribs & $2(0.06 \%)$ & $1(0.04 \%)$ & - \\
Agenesia or short 12 th ribs & - & - & $2(0.08 \%)$ \\
Hypoplasia of gallbladder & $12(0.36 \%)$ & $14(0.62 \%)$ & - \\
Bilobed gallbladder & - & $9(0.40 \%)$ & $2(0.08 \%)$ \\
Dilated renal pelvis & - & - & $3(0.12 \%)$ \\
Flexure of fore paws & $37(1.10 \%)$ & $2(0.09 \%)$ & $20(0.82 \%)$ \\
Flexure of fore paws + 13 th ribs & - & - & $1(0.04 \%)$ \\
Flexure of fore paws + dilated renal pelvis & - & - & $1(0.04 \%)$ \\
Delayed ossification of the extremities & $5(0.15 \%)$ & - & - \\
Number of fetuses reith unossified sternebra $V$ & not calculated & $176 / 963$ & $625 / 1339$ \\
& & $(18.28 \%)$ & $(46.68 \%)$ \\
\hline
\end{tabular}

were found in eight fetuses $(0.10 \%)$ of Himalayan rabbits, in two JW fetuses $(0.58 \%)$ [9], in $21 \mathrm{NZW}$ fetuses $(0.04 \%)$ [12], or nine NZW fetuses (0.28\%) [13] and in 37 Fauve de Bourgo- gne $(0.32, \%)$ [12]. Such malformations are rarely described by other authors $[3,4]$.

Among variations, the frequency of the 13 th ribs (Table 3) differed largely between the three Himalayan colonies but was lower than that of JW and NZW $[4,5,9,12,13,14]$, or Dutch belted rabbits (27.4\%) [8]. The low incidence of the 13 th ribs was also reported in another Himalayan colony [4]. Hypoplastic and bilobed gallbladder were rather common in Lab 2 only. The extrahepatic biliary tract of the NZW also shows a wide range of variations [6]. No morphologic deviations of gallbladder were observed in JW $[9$, 


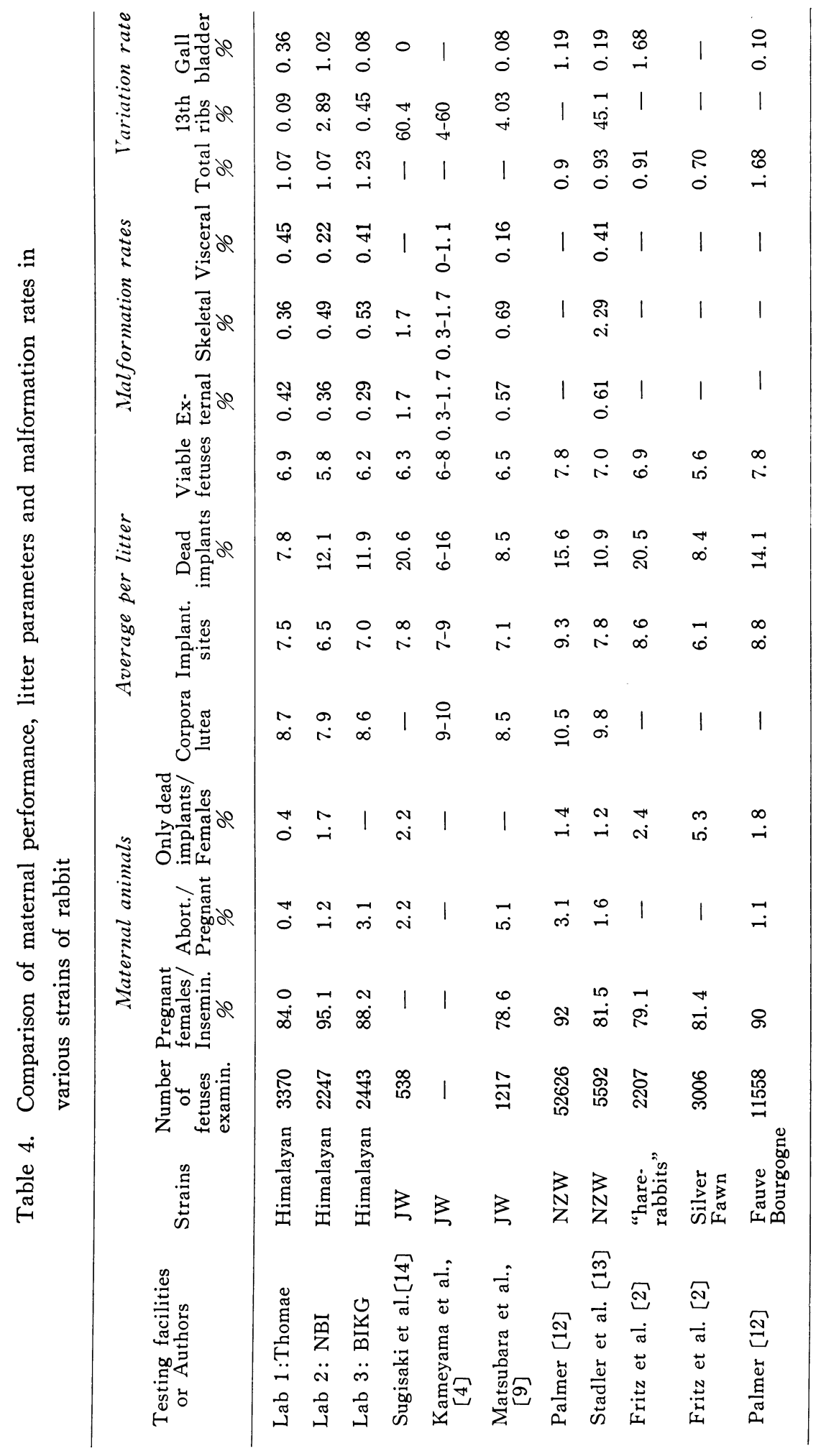


$14,15]$, whereas Palmer [12] reported missing $(0.32 \%)$ and bilobed $(0.31 \%)$ gallbladder in NZW. "Hare"-rabbits had no gallbladder in $3.27 \%$ [2]. Retina folds (4.57\%) were observed and histologically confirmed in Lab 1 only. The incidence of fetuses with unossified sternebra V (18.3-46.7,6) compared well with one JW-NIBS colony (16.1\%) [5], but was much higher than that of another JW-NIBS colony (3. 0\%) [9].

Such differences in type and number of abnormalities between laboratories working with the same strain of rabbit may have various reasons : differences in minor abnormalities like retina folds or hypoplastic gallbladder may be due to specific investigational methods of individual researchers. But this cannot hold for the majority of findings. For example, counting of ribs is done comparably in all laboratories with extremely differing results. Possibly, the interlaboratory variation may be an expression of the variability of this strain of rabbit.

The above data are additional to those previously published $[7,10]$ on the same strain, and show that the Himalayan rabbit is a useful test system in the field of reproduction toxicology.

\section{References}

[1] Cozens, D. (1965). Abnormalities of the external form and of the skeleton in the New Zealand White rabbit. Fd. Cosmet. Tox. 3, 695-700

[2] Fritz, H., Grauwiler, J., Hummler, H., Lindt, S., and Schoen, H. (1978). Collection of control data from teratological experiments on mice, rats, and rabbits. A group study. Arzneim.-Forsch. 28, 1410-1413

[3] Hartman, H. (1974). The fetus in experimental teratology. In Weisbroth, S.. pp. 91-153, Flatt, R. and Kraus, A. (eds) The Biology of the Laboratory Rabbit. Academic Press N. Y. and London.

[4] Kameyama, Y., Tanimura, T., and Yasuda, M. (1980). Spontaneous malformations in laboratory animals. ('ong. Anom. 20, 25-106

[5] Kawashima, M., Tanigawa, H., Kosazuma, T., and Tanaka, O. (1975). Individual differences of the skeletal development of the fetuses of 29 days of pregnancy in JW-NIBS strain rabbits. Cong. Anom. 15, 258-259

[6] Lee, S. (1978). Anomalies in the extrahepatic biliary tract of the rabbit. Lab. Animals 12, 7172

[ 7 ] Lehmann, H., and Niggeschulze, A. (1971). The teratologic effects of thalidomide in Himalayan rabbits. Tox. appl. Pharmacol. 18, 208-219

[8] Markham, J., Emmerson, J., and Owen, N. (1971) Teratogenicity studies of methadone $\mathrm{HCl}$ in rats and rabbits. Nature 233, 342-343

[9] Matsubara, Y., Yamanaka, H., and Suzuki, Y. (1984). Spontaneous malformations in JW-NIBS rabbits. Exp. Animals 33, 227-232

[10] Matsuo, A., Kazuta, H., and Kast, A. (1981). Identification of a substrain of Himalayan rabbits produced in Japan. Exp. Animals 30, 269-273

[11] Palmer, A. (1968). Spontaneous malformations of the New Zealand White rabbit: the background to safety evaluation tests. Lab. Animals 2, 195206

[12] Palmer, A. (1978) Hereditary congenital malformation in rabbits. $\ln$ Pathology of Laboratory Animals, Vol. 2, pp1848-1860, Benirschke, K., Garner, F., and Jones, T. (edit.) Sp ringer-Verlag, N.Y., Heidelberg, Berlin

[13] Stadler, J., Kessedjian, M. and Perraud, J.(1983). Use of the New Zealand White rabbit in teratology : incidence of spontaneous and drug-induced malformations. Fd. Chem. Toxic. 21, 631-636

[14] Sugisaki, T., Iijima. K., Ta kayame, K., Hayashi. S., and Miyamoto, M. (1979). The incidences of spontaneous fetal anomalies in Japanese White rabbits. Exp. Animals 28, 273-278

[15] Sugiyama, O., and Shiota, S. (1978). Background data of JW/CSK strain rabbits in teratology testing. Exp. Animals, 13th Meeting (abstr.) p72

\section{Himalayan ウサギの自然発生奇形および胎仔計測值}

$$
\begin{gathered}
\text { ホルスト・レーマン・松尾朝紀* } \\
\text { アドルフ・ニッゲシュルツェ**.アレキサンダー・カスト* } \\
\text { ドクターカールトーメ有限会社実験病理部 } \\
\text { *日木ボーリンガーインゲルハイム株式会社 } \\
\text { **ベリンガーインゲルハイム合資会社实験病理部 }
\end{gathered}
$$

Himalayan ウサギを使用している研究施没 3 力所で, これまでに 蓄積された同系ウサギの生殖能に関する背
景データを比較検㩆した。対象となる同腹仔はすべて 試験対照群に用いた母動物から得られたものである。 
Himalayan ウサギでは, 他の系統と比較して 妊娠率 （84.0〜95.1\%）は高加たが, 黄体数（7.9〜8.7）, 着床数（6.5 7.5）求よび生存胎仔数（5.8〜6.9）の
平均值はやや低かった。生存胎仔 8,060 例の検索で, 奇 形胎仔は 90 例 (1.12\%), また変異胎仔は 425 例 $(5.27$ \%)に認められた。 